\title{
PERLINDUNGAN HUKUM PERDATA DAGANG TERHADAP PEMILIK RAHASIA DAGANG DI INDONESIA
}

\author{
Lili Anggraini 1)* dan Hasyim ${ }^{2)}$ \\ ${ }^{1}$ Ekonomi, Universitas Negeri Medan \\ Email: Anggrainilili539@gmail.com \\ ${ }^{2}$ Ekonomi, Universitas Negeri Medan \\ Email : Mashasyim@gmail.com
}

\begin{abstract}
Abstrak :
Penelitian ini bertujuan untuk mengetahui mengenai perlindungaan hukum perdata dagang terhadap pemilik rahasia dagang di Indonessia. Rahasia dagang yang merupakan suatu bentuk hak atas kepemilikan intelektual (HaKI) tersendiri yang berbeda dari bentuk HaKI lainnya, sehingga tidaklah tepat jika ketentuan yang dibuat hanya sekedar peraturan pelaksanaan dari undang-undang HaKI lainnya. Maka dari itu Indonesia telah memiliki peraturan tentang rahasia dagang yang tertuang dalam undang-undang No. 30 Tahun 2000 tentang Rahasia Dagang (selanjutnya disebut undang-undang rahasia dagang) yang ditetapkan oleh pemerintah pada tanggal 20 Desember 2000. UU ini dibuat dalam rangka memajukan industri yang mampu bersaing dalam lingkup perdagangan nasional dan Internasional, dimana diperlukan adanya jaminan perlindungan terhadap rahasia dagang. Apabila terjadi sengketa bisnis antara pemilik/pemegang Rahasia Dagang dengan pihak ketiga yang berkaitan dengan pelaksanaan perjanjian, maka pemilik/pemegang Rahasia Dagang dapat menyelesaikan sengketa tersebut di luar pengadilan, yaitu dengan cara arbitrase atau alternatif penyelesaian sengketa.

Berdasarkan permasalahan yang dihadapi maka metode pendekatan yang digunakan dalam penelitian ini adalah metode pendekatan yuridis normative dengan menggunakan analisis kualitatif. Adapun data yang digunakan dalam penelitian ini berupa data sekunder.
\end{abstract}

Kata-kata Kunci : Rahasia Dagang, HaKI, Hukum Perdata Dagang 


\section{PENDAHULUAN}

Indonesia telah memiliki peraturan tentang rahasia dagang yang tertuang dalam undang-undang No. 30 Tahun 2000 tentang Rahasia Dagang (selanjutnya disebut undangundang rahasia dagang) yang ditetapkan oleh pemerintah pada tanggal 20 Desember 2000. UU ini dibuat dalam rangka memajukan industri yang mampu bersaing dalam lingkup perdagangan nasional dan Internasional, dimana diperlukan adanya jaminan perlindungan terhadap rahasia dagang, terutama dari tindakan persaingan curang,. UU rahasia dagang juga penting untuk menjamin perlindungan yang efektif terhadap pemilikan, penguasaan dan penggunaan rahasia dagang sebagai konsekuensi keikutsertaan Indonesia dalam persetujuan tentang aspek-aspek dagang dari hak atas kepemilikan intelektual (HaKI)

Sebelum lahirnya UU rahasia dagang ini pemerintah juga pernah membuat rancangan peraturan pemerintah (RPP) tentang undisclosed information. Akan tetapi RPP itu mempunyai kelemahan antara lain adalah karena peraturan perundangan yang dibuat adalah dalam bentuk peraturan pemerintah, padahal peraturan perundangan yang dibuat seharusnya dalam bentuk undang-undang. Hal ini disebabkan karena rahasia dagang merupakan suatu bentuk hak atas kepemilikan intelektual (HaKI) tersendiri yang berbeda dari bentuk HaKI lainnya, sehingga tidaklah tepat jika ketentuan yang dibuat hanya sekedar peraturan pelaksanaan dari undang-undang HaKI lainnya.

\section{TINJAUAN PUSTAKA}

Menurut Undang-Undang No. 30 Tahun 2000 pasal I angka I tentang Rahasia Dagang (UURD), menyatakan bahwa "Rahasia Dagang adalah informasi yang tidak diketahui oleh umum di bidang teknologi dan/ atau bisnis, mempunyai nilai ekonomi karena berguna dalam kegiatan usaha, dan dijaga kerahasiaannya oleh pemilik Rahasia Dagang."

Rahasia dagang (trade secret) dapat juga diartikan sebagai informasi yang tidak diketahui oleh umum di bidang teknologi dan atau bisnis dimana informasi tersebut bisa saja berupa dokumen ataupun data. Unsur nilai yang berharga di setiap dokumen atau data tersebut, dan oleh karenannya dijaga kerahasiaannya oleh si pemilik rahasia dagang tersebut (Muasyara, dkk :2).
NIAGAWAN Vol 7 No 3 November 2018

Berdasarkan latar belakang di atas, maka kita bisa melihat bahwa Rahasia Dagang adalah sebuah informasi yang sangat berharga untuk perusahaan, karenannya harus dijaga kerahasiaannya. Keberhargaan informasi ini, karena informasi tersebut dapat mendatangkan keuntungan ekonomis kepada perusahaan. Sedangkan yang dimaksud dengan hak Rahasia Dagang adalah hak atas Rahasia Dagang yang timbul berdasarkan Undang-Undang Rahasia Dagang.

Rahasia Dagang sebagai salah satu bagian dari HAKI, merupakan hak yang cukup tinggi dalam perkembangan aktivitas bisnis di Indonesia. Hal ini ditandai dengan keseriusan pemerintah dalam menangani permasalahan tersebut sehingga diundangkannya UU No. 30 Tahun 2000 tentang Rahasia Dagang yang mulai berlaku sejak 20 September 2000 dengan dilatarbelakangi oleh ratifikasi perjanjian WTO/TRIP's melalui UU No. 7 Tahun 1994 serta diundangkannya UU No. 5 Tahun 1999 tentang Larangan Praktek Monopoli dan Persaingan Tidak Sehat yang menunjukkan bahwa pokok pikiran dari UU Rahasia Dagang di Indonesia telah sejalan dengan pemikiran TRIP's sebagai bagian dari perjanjian dalam WTO.

Dalam era persaingan bisnis yang demikian ketat saat ini, perlindungan Rahasia Dagang merupakan kebutuhan yang tidak dapat ditawar-tawar lagi, sebab ketidakpastian atas masalah ini dapat menimbulkan konsekuensi makin maraknya persaingan tidak jujur (unfair competition) yang akan merusak iklim bisnis secara keseluruhan.

Ada 3 perbedaan pokok antara Rahasia Dagang dengan bentuk HAKI lainnya seperti hak cipta, paten dan merek. Ketiga perbedaan itu dapat diuraikan sebagai berikut :

a. Bentuk HAKI lain tidak bersifat rahasia. Bentuk HAKI lain mendapat perlindungan karena merupakan sejenis kekayaan yang dimiliki orang lain. Memang, kecuali kalau informasi mengenai suatu penemuan diungkapkan, perlindungan paten tidak dapat diperoleh dari negara. Kalau karya-karya yang dilindungi hak cipta atau sebuah merek tidak digunakan secara umum, maka tidak ada nilai komersialnya. Rahasia Dagang mendapat perlindungan karena sifat rahasianya menyebabkan informasi itu bernilai. Rahasia Dagang terdiri 
informasi yang hanya bernilai komersial kalau kerahasiannya tidak hilang.

b. Rahasia Dagang mendapat perlindungan meskipun tidak mengandung nilai kreativitas atau pemikiran baru. Yang penting adalah Rahasia Dagang tersebut tidak diketahui secara umum. Misalnya, sebuah sistem kerja yang efektif, barangkali tidak begitu kreatif, tetapi keefektifan dan kerahasiaannya menyebabkan informasi itu bernilai komersial.

c. Bentuk HAKI lain selalu berupa bentuk tertentu yang dapat ditulis, digambar atau dicatat secara persis sesuai dengan syarat pendaftaran yang ditetapkan oleh instansi pemerintah. Rahasia Dagang tidak semestinya ditulis. Yang penting, bukan bentuk tulisan atau pencatatan informasi yang persis, tetapi penggunaan konsep, ide atau informasinya sendiri yang dapat diberikan kepada pihak lain secara lisan. Hal ini berbeda dengan hak paten atau merek.

Meskipun ada perbedaan antara Rahasia Dagang dengan bentuk HAKI lainnya, akan tetapi dari perbedaan tersebut ternyata masih ada hubungan tumpang tindih. Hubungan tumpah tindih ini, sangat jelas dalam hal paten. Kalau sebuah perusaan mempunyai suatu penemuan, mereka dapat memilih antara menjaga kerahasiaan dari prinsip yang mendasari penemuan tersebut atau mempatenkan penemuan itu. Kalau perusahaan tersebut memilih untuk menjaga kerahasiaan penemuannya, informasi itu mendapat perlindungan hukum selama kerahasiaannya tidak hilang. Sebaliknya apabila perusahaan tersebut memilih untuk mempatenkan penemuan-nya, maka sifat kerahasiaannya hilang, namun perusahaan tersebut memperoleh perlindungan paten selama jangka waktu terbatas. Selama masa berlaku paten berakhir, perlindungan untuk penemuan tersebut juga hilang. Bagaimanapun juga, pemegang ha katas paten diberikan jaminan perlindungan selama masa berlaku yang terbatas, perlindungan dari hukum Rahasia Dagang juga membawa risiko bahwa hak itu akan hilang sejalan dengan hilangnya sifat kerahasiaan informasi tersebut.

Namun demikian, untuk penemuan yang mudah dibongkar atau dianalisis dan diproduksi ulang, perlindungan paten adalah jenis
NIAGAWAN Vol 7 No 3 November 2018 perlindungan yang lebih aman, meskipun ada jangka waktu perlindungan yang terbatas. Tentu ini tidak menjadi soal, manakala langkah invensi dapat dilakukan secara terus-menerus terhadap paten tersebut sehingga ketika hak itu akan berakhir sudah dapat dimintakan paten baru.

Subjek hak atas Rahasia Dagang adalah pemilik rahasia itu sendiri. Pemilik Rahasia Dagang dapat menggunakan dan memanfaatkan Rahasia Dagang tersebut maupun mencegah pihak lain untuk menggunakannya. Akan tetapi, seperti halnya dengan jenis HAKI lain, si pemilik juga boleh memberi lisensi kepada pihak lain untuk menggunakan Rahasia Dagang itu selama jangka waktu tertentu, melalui perjanjian lisensi. Perjanjian lisensi menimbulkan kewajiban bagi si penerima lisensi untuk menjaga kerahasiaannya.

Pasal 1 angka 2 Undang-Undang Rahasia Dagang menyatakan bahwa Hak Rahasia Dagang adalah Hak Atas Rahasia Dagang yang timbul berdasarkan UndangUndang Rahasia Dagang ini (Undang-Undang Nomor 30 Tahun 2000 Tentang Rahasia Dagang). Hak Rahasia Dagang ini diklasifikasikan sebagai Hak Milik, sehingga sebagai Hak Milik, Rahasia Dagang dapat beralih dan dialihkan kepada pihak lain.

Undang-Undang Rahasia Dagang dalam Pasal 5 ayat (1) menyebutkan peristiwaperistiwa hukum yang dapat mengakibatkan beralihnya Hak Rahasia Dagang. Pengalihan Rahasia Dagang dapat dilakukan melalui proses Pewarisan, Hibah, Wasiat, Perjanjian Tertulis, atau sebab-sebab lain yang dibenarkan oleh peraturan perundang-undangan.

Khusus untuk pengalihan hak atas dasar perjanjian, diperlukan adanya suatu Pengalihan Hak yang didasarkan pada pembuatan suatu akta, terutama akta otentik. Hal ini penting mengingat aspek yang dijangkau begitu luas dan pelik, selain untuk menjaga kepentingan masingmasing pihak yang mengadakan Perjanjian Pengalihan Hak Atas Rahasia Dagang tersebut.

Pengalihan Hak Rahasia Dagang yang disebabkan oleh "sebab-sebab lain yang dibenarkan oleh peraturan perundang-undangan" dapat dijelaskan di sini misalnya putusan pengadilan yang menyangkut kepailitan.

Di samping itu Pemilik Rahasia Dagang atau Pemegang Hak Rahasia Dagang juga dapat memberikan lisensi kepada pihak lain berdasarkan perjanjian lisensi untuk melaksanakan atau menggunakan Hak Rahasia 
Dagang dalam kegiatan yang bersifat komersial (Pasal 6 Undang-Undang Rahasia Dagang).

Pasal 5 ayat (1) UU Rahasia Dagang menyebutkan beberapa cara pengalihan Hak Rahasia Dagang kepada orang lain, yakni bahwa Hak Rahasia Dagang dapat beralih atau dialihkan dengan Pewarisan, Hibah, Wasiat, Perjanjian Tertulis atau sebab-sebab lain yang dibenarkan oleh peraturan perundang-undangan. Sebagai Hak Milik, Rahasia Dagang dapat beralih atau dialihkan kepada pihak lain melalui cara-cara yang telah disebutkan di atas.

Pengalihan Hak Rahasia Dagang melalui Pewarisan terjadi demi hukum sebagai akibat meninggalnya pihak pemilik Rahasia Dagang, jelas mengakibatkan beralihnya secara hukum semua hak-hak dan kewajiban yang melekat pada Rahasia Dagang dari pewaris (Pemilik Rahasia Dagang), sedangkan Pengalihan melalui Hibah dan Wasiat tidak terjadi demi hukum, melainkan harus dilakukan melalui perbuatan hukum tertentu, sehingga hak atas Rahasia Dagang menurut hukum sah beralih atau dialihkan kepada penerima hibah dan penerima wasiat. Peristiwa hukum tertentu tersebut didasarkan pada hukum yang mengatur mengenai hibah dan wasiat sesuai dengan golongan penduduknya.

Demikian pula Pengalihan Hak Rahasia Dagang dapat dilakukan melalui Perjanjian yang tertulis (akta) atau dapat dilakukan karena sebabsebab lain yang dibenarkan peraturan perundang-undangan seperti melalui putusan pengadilan yang menyangkut kepailitan.

Pengalihan Hak Rahasia Dagang diatas bersifat limitatif artinya proses Pengalihan Hak Rahasia Dagang tersebut tidak boleh mencantumkan klausula time constraint, dengan kata lain pengalihan hak itu bersifat final dalam arti tidak boleh dibatasi oleh waktu.

Mempertahankan Eksistensi Rahasia Dagangnya untuk Mengatasi Persaingan Tidak Sehat

Hak dan Kewajiban Pemilik Rahasia Dagang

a. Hak Pemilik Rahasia Dagang

Pasal 4 Undang-Undang Rahasia Dagang mengatur tentang kewenangan atau hak yang dimiliki oleh pemilik Rahasia Dagang terhadap Rahasia Dagangnya untuk :

1. Menggunakan sendiri Rahasia Dagang yang dimilikinya;

2. Memberikan lisensi kepada atau melarang pihak lain untuk menggunakan
NIAGAWAN Vol 7 No 3 November 2018 Rahasia Dagang atau mengungkapkan Rahasia Dagang itu kepada pihak ketiga untuk kepentingan yang bersifat komersial.

Berdasarkan pasal ini, pemilik Rahasia Dagang mempunyai Hak Monopoli untuk menggunakan sendiri Rahasia Dagang yang dimilikinya dalam kegiatan bisnis untuk memperoleh keuntungan ekonomis. Ketentuan ini juga berarti bahwa hanya pemilik Rahasia Dagang yang berhak untuk memberikan izin kepada pihak lain untuk menggunakan Rahasia Dagang yang dimilikinya melalui perjanjian lisensi. Selain itu, pemilik Rahasia Dagang juga berhak melarang pihak lain untuk menggunakan atau mengungkapkan Rahasia Dagang yang dimilikinya kepada pihak ketiga apabila pengungkapan tersebut dilakukan untuk kepentingan yang bersifat komersial

Pada Pasal 1 ayat (2) Undang- Undang Nomor 30 Tahun 2000 Tentang Rahasia Dagang, dinyatakan bahwa "Hak Rahasia Dagang adalah Hak Atas Rahasia Dagang yang timbul berdasarkan Undang-Undang ini”.

Berdasarkan ketentuan ini, maka secara eksplisit diatur tentang hak dari pemilik Rahasia Dagang (Pasal 4), yaitu:

a. Menggunakan sendiri Rahasia Dagang yang dimilikinya;

b. Memberikan lisensi kepada atau melarang pihak lain untuk mengunakan Rahasia Dagang itu kepada pihak ketiga untuk kepentingan yang bersifat komersial.

Berdasarkan ketentuan ini, pemilik Rahasia Dagang mempunyai hak monopoli untuk menggunakan sendiri Rahasia Dagang yang dimiliknya dalam kegiatan bisnis dan bersifat komersil untuk memperoleh keuntungan. Hal ini berarti bahwa hanya pemilik Rahasia Dagang saja yang berhak memberikan izin kepada pihak lain untuk mengunakan Rahasia Dagang yang dimiliknya melalui perjanjian lisensi. Lisensi adalah izin yang diberikan oleh pemegang Hak Rahasia Dagang kepada pihak lain melalui suatu perjanjian berdasarkan pemberian hak (bukan Pengalihan Hak) untuk menikmati manfaat ekonomi dari suatu Rahasia Dagang yang diberi perlindungan dalam jangka waktu tertentu dan syarat tertentu (Pasal 5 Undang-Undang Rahasia Dagang).

Dari rumusan tersebut dapat ditarik beberapa unsur, yaitu: 
NIAGAWAN Vol 7 No 3 November 2018

1. Adanya izin yang diberikan oleh pemegang Hak Rahasia Dagang.

2. Izin tersebut diberikan dalam bentuk perjanjian.

3. Izin tersebut merupakan pemberian hak untuk menikmati manfaat ekonomi (yang bukan bersifat pengalihan Hak Rahasia Dagang).

4. Izin tersebut diberikan untuk Rahasia Dagang yang memenuhi syarat untuk dilindungi.

5. Izin tersebut diberikan dengan waktu tetentu dan syarat tertentu.

b. Kewajiban Pemilik Rahasia Dagang Pemilik Rahasia Dagang memiliki suatu kewajiban atas Rahasia Dagang tersebut. Pemilik Rahasia Dagang wajib memelihara dan menjaga kerahasiaan informasi yang dimiliknya dari pihak-pihak yang berusaha dengan berbagai cara memperolehnya untuk kepentingan usahanya.

Kewajiban dalam memelihara kerahasiaan ini dapat ditempuh melalui ketentuan-ketentuan yang bersifat implisit. Pada prinsipnya hukum akan memberikan perlindungan apabila pemilik Rahasia Dagang tersebut menjalankan kewajibannya untuk menjaga Rahasia Dagangnya.

Pemilik Rahasia Dagang juga dibebani kewajiban, yaitu harus bersedia mengungkapkan setiap bagian dari Rahasia Dagangnya serta proses penggunaannya secara lengkap untuk kepentingan pembuktian dihadapan pengadilan. Hal ini memang mengandung resiko karena Rahasia Dagang yang dimilikinya dapat terpublikasikan. Oleh karena itu, hakim dapat meminta agar sidang dilakukan secara tertutup demi kepentingan bisnis dari pemiliknya serta mengurangi tingkat kerugian yang dideritanya.

\section{METODE PENELITIAN}

Berdasarkan permasalahan yang dihadapi maka metode pendekatan yang digunakan dalam penelitian ini adalah metode pendekatan yuridis normatif, yaitu suatu prosedur penelitian ilmiah untuk menemukan kebenaran berdasarkan logika keilmuan hukum dari sisi normatif untuk menghasilkan suatu ketajaman analisis hukum berdasarkan doktrin dan norma yang telah ditetapkan dalam sistem hukum melalui analysis of the primary and secondary Umeterials. Pada penelitian ini menggunakan aspek yuridis dalam penelitian hukum ini melingkupi ilmu hukum Undangundang Nomor 30 Tahun 2000 tentang Rahasia Dagang.

Spesifikasi penelitian yang digunakan bersifat deskriptif analitis, yang mana penulisan hukum ini merupakan atau menggambarkan suatu peraturan perundang-undangan yang berlaku, yaitu Undang-Undang Rahasia Dagang dikaitkan dengan teori hukum dan praktik yang menyangkut objek masalah, yaitu penerapan sanksi bagi pelaku penyebarluasan rahasia dagang dalam persaingan tidak sehat (curang) yang dihadapi oleh pemilik rahasia dagang.

Penelitian ini bersifat deskriptif, sehingga data yang digunakan adalah data sekunder, yaitu data yang diperoleh melalui bahan kepustakaan yang erat hubungannya dengan bahan-bahan hukum primer dan dapat membantu menganalisis dan memahami bahan hukum primer. Contohnya adalah seperti laporan hasil penelitian, disertasi, jurnal, artikel, mengenai rahasia dagang.

Dalam penelitian ini, semua data yang terkumpul dalam penelitian ini bersifat sekunder akan dianalisis secara kualitatif. Analisis kualitatif merupakan analisis data yang menggunakan penjelasan berupa kumpulan kata / uraian dengan prosedur teoritis serta perkiraan yang logis. Menurut Umar (2000:38) menyebutkan "tujuan penelitian kualitatif adalah memaparkan atau mendeskripsikan hal - hal yang berhubungan dengan objek penelitian".

\section{HASIL DAN PEMBAHASAN}

a. Perlindungan hukum terhadap Rahasia Dagang

Kebutuhan perlindungan hukum terhadap Rahasia Dagang sesuai dengan salah satu ketentuan dalam Agreement on Trade Related Aspects of Intellectual Property Rights (Persetujuan TRIPs) yang merupakan lampiran dari Agreement Establishing the World Trade Organization on Trade Organization (Persetujuan Pembentukan Organisasi Perdagangan Dunia), sebagaimana telah diratifikasi oleh Indonesia dengan UU No. 7 Tahun 1994. Adanya perlindungan hukum terhadap Rahasia Dagang tersebut akan mendorong lahirnya temuan baru yang meskipun diperlakukan secara rahasia, tetap mendapat perlindungan hukum, baik dalam rangka kepemilikan, penguasaan, maupun pemanfaatannya oleh penemunya. Untuk mengelola administrasi Rahasia Dagang, pada 
saat ini pemerintah menunjuk Departemen Kehakiman dan Hak Asasi Manusia c.q. Direktorat Jenderal Hak Atas Kekayaan Intelektual untuk melakukan pelayanan di bidang Hak Atas Kekayaan Intelektual.

Undang-Undang Rahasia Dagang No. 30 Tahun 2000 memberikan lingkup perlindungan Rahasia Dagang yaitu meliputi metode produksi, metode pengolahan, metode penjualan, atau informasi lain di bidang teknologi dan/atau bisnis yang memiliki nilai ekonomi dan tidak diketahui oleh masyarakat umum.

Suatu Rahasia Dagang akan mendapatkan perlindungan apabila informasi tersebut sejatinya bersifat rahasia, mempunyai nilai ekonomi, dan dijaga kerahasiaannya melalui upaya-upaya sebagaimana mestinya. Bersifat rahasia, maksudnya bahwa informasi tersebut hanya diketahui oleh pihak tertentu atau tidak diketahui secara umum oleh masyarakat. Mempunyai nilai ekonomi, maksudnya bahwa sifat kerahasiaan informasi tersebut dapat digunakan untuk menjalankan kegiatan usaha yang bersifat komersial atau dapat meningkatkan keuntungan secara ekonomi. Informasi dianggap dijaga kerahasiaannya apabila pemilik atau para pihak yang menguasainya telah melakukan langkah-langkah yang layak dan patutUndangUndang Rahasia Dagang No. 30 Tahun 2000 memberikan lingkup perlindungan Rahasia Dagang yaitu meliputi metode produksi, metode pengolahan, metode penjualan, atau informasi lain di bidang teknologi dan/atau bisnis yang memiliki nilai ekonomi dan tidak diketahui oleh masyarakat umum.

Suatu Rahasia Dagang akan mendapatkan perlindungan apabila informasi tersebut sejatinya bersifat rahasia, mempunyai nilai ekonomi, dan dijaga kerahasiaannya melalui upaya-upaya sebagaimana mestinya. Bersifat rahasia, maksudnya bahwa informasi tersebut hanya diketahui oleh pihak tertentu atau tidak diketahui secara umum oleh masyarakat. Mempunyai nilai ekonomi, maksudnya bahwa sifat kerahasiaan informasi tersebut dapat digunakan untuk menjalankan kegiatan usaha yang bersifat komersial atau dapat meningkatkan keuntungan secara ekonomi. Informasi dianggap dijaga kerahasiaannya apabila pemilik atau para pihak yang menguasainya telah melakukan langkah-langkah yang layak dan patut.

Dalam ranah HAKI pada dasarnya perlindungannya berintikan pengakuan terhadap
NIAGAWAN Vol 7 No 3 November 2018 hak atas kekayaan dan hak untuk menikmati kekayaan itu dalam waktu tertentu.Artinya selama waktu tertentu pemilik atau pemegang hak atas HAKI dapat mengijinkan atau melarang untuk mengetahui atau menyebarluaskan informasi (Rahasia Dagang).

Pelanggaran Rahasia Dagang terjadi apabila seseorang dengan sengaja mengungkapkan Rahasia Dagang, mengingkari kesepakatan atau mengingkari kewajiban tertulis atau tidak tertulis untuk menjaga Rahasia Dagang yang bersangkutan.Untuk mengatasi adanya pelanggaran tersebut maka amat diperlukan perlindungan hukum bagi pemilik dan atau pemegang HAKI yang bersangkutan.

Apabila seseorang merasa pihak lain telah melanggar hak Rahasia Dagang yang dimilikinya, maka ia sebagai pemegang hak Rahasia Dagang atau pihak lain sebagai penerima lisensi dapat menggugat siapapun yang dengan sengaja dan tanpa hak Rahasia Dagang. Seseorang dianggap melanggar Rahasia Dagang pihak lain apabila ia memperoleh atau menguasai Rahasia Dagang tersebut dengan cara yang bertentangan dengan peraturan perundangundangan yang berlaku.

Disamping itu juga ada perbuatan yang tidak dianggap pelanggaran Rahasia Dagang yakni apabila :

1. Tindakan pengungkapan Rahasia Dagang atau penggunaan Rahasia Dagang tersebut didasarkan pada kepentingan pertahanan dan keamanan, kesehatan atau keselamatan masyarakat ;

2. Tindakan rekayasa ulang atas produk yang dihasilkan dari penggunaan Rahasia Dagang milik orang lain yang dilakukan semata-mata untuk kepentingan pengembangan lebih lanjut produk yang bersangkutan. Yang dimaksud dengan rekayasa ulang (reverse engineering) dalam hal ini adalah suatu tindakan analisis dan evaluasi untuk mengetahui informasi tentang suatu teknologi yang sudah ada.

Disamping dapat melakukan upaya gugatan melalui pengadilan, pemilik Rahasia Dagang atau pihak yang merasa dirugikan dapat menempuh upaya lain yakni melalui penyelesaian sengketa melalui Arbitrase atau Alternatif Penyelesaian Sengketa (ADR). 
b. Perlindungan Hukum Terhadap Peemilik Rahasia Dagang Dari Aspek Perdata

Dalam sistem Hukum Perdata di Indonesia, dimana dapat dikatakan HAKI sebagai hak kebendaan, yang merupakan hak atas suatu benda, yang bersumber dari hasil karya otak atau hasil kerja rasio otak manusia yang menalar dan hasil kerjanya itu merupakan benda immaterial (benda tidak berwujud)10. Hal ini terdapat dalam Pasal 499 KUHPerdata tentang "benda" yang dapat diklasifikasikan ke dalam berbagai kategori termasuk benda berwujud dan tidak berwujud. Karena merupakan hasil dari pikiran manusia, maka dapat disimpulkan bahwa hasil kerja dari otak manusia sebagai hak atas kekayaan intelektual yang bersifat eksklusif atau mempunyai nilai ekonomi11 dan perlu mendapatkan suatu pengakuan dan sekaligus perlindungan hukum.

Pemilik Rahasia Dagang wajib memelihara dan menjaga kerahasiaan dari informasi yang dimilikinya. Hal itu dapat dilakukan melalui berbagai langkah seperti melalui pembuatan kontrak yang isinya secara eksplisit mewajibkan pihak lain untuk tidak membocorkan rahasia itu secara tertulis. Kontrak tertulis semacam ini akan sangat membantu khususnya untuk menghindarkan kesalahpahaman atas ruang lingkup yang harus dirahasiakan. Kewajiban dalam memelihara kerahasiaan ini juga ddapat ditempuh melalui pembuatan ketentuan-ketentuan kontrak yang bersifat implisit. Pada prinsipnya hukum akan melindungi kerahasiaan itu berdasarkan asasasas hukum perjanjian yang menyatakan bahwa perjanjian itu tidak hanya mencakup apa yang telah seccara eksplisit diperjanjikan, tetapi juga mencakup kebiasaan-kebiasaan meskipun tidak secara tegas dinyatakan seperti tercantum dalam Pasal 1347 BW yang berbunyi :

" Hal-hal yang menurut kebiasaan selamanya diperjanjikan, dianggap secara diam-diam dimasukkan dalam persetujuan, meskipun tidak dengan tegas dinyatakan".

Rahasia Dagang antara lain dilindungi berdasarkan prinsip hukum perdata berdasarkan perbuatan melawan hukum (onrechmatige daad). Berdasarkan perbuatan melawan hukum ini secara perdata mengakibatkan perikatan dan memajukan kepada pihak yang membuat kerugian itu memberikan ganti kerugian. Pasal 1365 BW selengkapnya mengatakan :

"Perbuatan melawan hukum merupakan setiap perbuatan yang melanggar hukum yang
NIAGAWAN Vol 7 No 3 November 2018 membawa kerugian bagi orang lain, hal mana mewajibkan kepada pihak yang melakukan kesalahan itu memberi ganti kerugian kepada pihak yang dirugikan tersebut".

Jika dikaitkan dengan perlindungan asas Rahasia Dagang, maka pihak yang telah melanggar hak-hak atas suatu informasi rahasia yang dimiliki seseorang yang memiliki nilai komersial dapat dikualifikasikan sebagai perbuatan melawan hukum. Ketentuan Pasal 1365 BW ini pada prinsipnya bertujuan memberikan substansi perdata terhadap semua bentuk pelanggaran yang merugikan pihak lain14. Salah satu bentuk perjanjian untuk melindungi Rahasia Dagang adalah dalam bentuk perjanjian merahasiakan (secrecy agreement). Perjanjian ini dimaksudkan untuk melindungi tidak saja data dan informasi yang juga termasuk ke dalam Rahasia Dagang tapi mencakup juga pengalaman teknik (technical experience) berkenaan dengan proses-proses pengolahan, perlengkapan, peralatan, bahanbahan, tata cara pengoperasian, tata cara pengendalian mutu, tata cara keamanan dan mencakup pula informasi mengenai formulaformula yang memiliki nilai komersial yang tinggi.

Mengenai hak dan kewajiban subjek perjanjian diatur bahwa perusahaan pemberi Rahasia Dagang bersedia mengungkapkan kepada penerima informasi-informasi yang diperlukan dalam waktu tertentu dengan catatan penerima akan tetap merahasiakan dan tidak akan mengungkapkan kepada orang lain akan menggunakannya untuk kepentingan di luar perjanjian ini. Kewajiban merahasiakan ini juga berlaku terhadap perjanjian-perjanjian selanjutnya yang mungkin dilakukan oleh pihak penerima. Pengecualian atau pembatasan atas isi perjanjian ini dimungkinkan jika informasiinformasi yang digunakan oleh penerima meliputi hal-hal sebagai berikut :

a. yang dimiliki penerima sebelum diterimanya perjanjian ini dan tidak diperoleh sebelumnya baik langsung maupun tidak langsung, menurut pengetahuan penerima atau wakilwakilnya, dari pemberi atau wakilwakilnya;

b. yang pada waktu pengungkapan kepada penerima atau wakil-wakilnya adalah atau sesudah menjadi melalui tidak dilakukannya atau kelalaian untuk melakukan pada pihak penerima atau 
para wakilnya bagian dari milik umum melalui publikasi atau lainnya;

c. atau yang disediakan kepada penerima dan pihak-pihak laiunnya sebagai tanpa membatasi pada pengungkapan atau penggunaannya.

Langkah-langkah yang diambil dalam melindungi Rahasia Dagang melalui sistem hukum kontrak yang dilakukan para pelaku bisnis adalah salah satu strategi yuridis untuk melindungi Rahasia Dagang itu sendiri, yang dapat dijadikan bukti bahwa pemiliknya secara sungguh-sungguh telah melakukan perlindungan optimum terhadap Rahasia Dagang yang dimilikinya yang merupakan salah satu syarat informasi yang dikategorikan sebagai Rahasia Dagang. Segala informasi yang berkenaan atau yang menyangkut pelanggan, penjual keliling (vendor), pemberi lisensi (licensor), penerima lisensi (licensee), atau menyangkut pihak ketiga yang melakukan transaksi bisnis dengan perusahaan yang tertutup juga harus dirahasiakan kecuali jika dilakukan dengan prinsip tertulis dari pusat.

Ketentuan-ketentuan kontrak yang dibuat seperti dipaparkan sebelumnya merupakan bagian penting dari sistem perlindungan Rahasia Dagang secara keseluruhan, sehingga dapat disimpulkan bahwa pencantuman dan pembuatan perjanjian ini yang dimiliki dua arti strategis, yaitu :

a. Memberikan kejelasan dalam hubungan antara pemilik informasi dan karyawan yang menunjukkan batas-batas apa yang boleh dan tidak boleh dilakukan oleh karyawan berkenaan dengan rahasia perusahaan itu sehingga para pihak mengetahui secara jelas batas hak dan kewajiban masing-masing untuk menghindari terjadinya kesalahpahaman dalam penafsiran hak dan kewajiban.

b. Pembuatan perjanjian tentang perlindungan informasi atas Rahasia Dagang ini juga merupakan salah satu langkah untuk menjamin kepastian hukum jika dikemudian hari terdapat sengketa dengan karyawan atau pihak ketiga. Perjanjian ini akan dapat dijadikan bukti otentik bahwa perusahaan memiliki informasi yang sangat rahasia sifatnya dan hanya dipergunakan untuk kegiatan bisnis perusahaan itu saja.
NIAGAWAN Vol 7 No 3 November 2018 Walaupun Rahasia Dagang bersifat keperdataan, yang mengatur hubungan antara individu yang memiliki (hak) Rahasia Dagang dengan pihak ketiga, yang berhubungan dengan informasi yang terkandung dalam Rahasia Dagang, guna melindungi kepentingan pemilik dan pemegang Rahasia Dagang secara khusus dan usaha pada umumnya. Negara memberikan sanksi pidana kepada pelanggar hak Rahasia Dagang sebagaimana diatur dalam Pasal 17 ayat (1) UU No. 30 Tahun 2000. Walau demikian tindakan pemberian sanksi oleh Negara ini pun diharapkan kembali kepada kepentingan dari pihak yang dilindungi dengan menjadikan tindak pidana tersebut sebagai delik aduan (Pasal 17 ayat (2)). Penegakan hukum terhadap pelanggaran dalam bidang Rahasia Dagang lebih berat dibandingkan dengan penegakan hukum HAKI lainnya. Hal ini disebabkan oleh beberapa hal, yaitu :

a. Rahasia Dagang dibandingkan dengan bentuk HAKI lainnya kurang dikenal oleh masyarakat, sehingga menyebabkan penegakan hukum di bidang ini lebih sulit dibanding HAKI lain. b. Pelanggaran atas Rahasia Dagang dalam aktivitas bisnis di Indonesia cenderung terjadi karena kurangnya pemahaman daripada pelaku bisnis terhadap bidang ini.

b. Perlakuan yang tidak semestinya terhadap Rahasia Dagang oleh pemilik Rahasia Dagang dalam hal ini para pelaku bisnis di Indonesia, yang menyebabkan informasi rahasia tersebut berubah menjadi milik umum (public domain) yang justru sebaliknya merugikan pemiliknya.

c. Belum adanya mekanisme yang efektif untuk mensosialisasikan UU Rahasia Dagang yang dilakukan oleh pemerintah, walaupun UU tersebut berlaku secara efektif.

\section{KESIMPULAN DAN SARAN Kesimpulan}

Berdasarkan pembahasan diatas, maka dapat ditarik kesimpulan bahwa: (1) Untuk mempertahankan Rahasia Dagang pemilik atau pemegang Rahasia Dagang dapat melakukan berbagai cara yang sesuai dengan hukum yang berlaku. (2) Pemilik rahasia dagang dalam menjaga nilai kerahasiaan informasi rahasia 
dagang yang dimiliki harus bersikap aktif dan represif. Dimana perlindungan yang diatur dalam UU Rahasia Dagang No. 30 Th. 2000 diberikan apabila pemilik rahasia dagang atau pemegang rahasia dagang telah melakukan langkah-langkah untuk menjaga rahasia dagang yang dimilikinya. (3) Apabila terjadi sengketa bisnis antara pemilik/pemegang Rahasia Dagang dengan pihak ketiga yang berkaitan dengan pelaksanaan perjanjian, maka pemilik/pemegang Rahasia Dagang dapat menyelesaikan sengketa tersebut di luar pengadilan, yaitu dengan cara arbitrase atau alternatif penyelesaian sengketa.

\section{SARAN}

Adapun saran yang diberikan adalah (1) Dengan berlakunya Undang-Undang Nomor 30 Tahun 2000 Tentang Rahasia Dagang yang sesuai dengan standar TRIPs, sewajarnyalah pemerintah mensosialisasikannya kepada masyarakat terutama kepada pelaku usaha yang pada umumnya tidak memahami manfaat dari Rahasia Dagang yang dimilikinya terhadap aktivitas bisnisnya sehingga menganggap informasi rahasia tersebut sebagai informasi umum dan milik umum. (2) Upaya perlindungan hukum melalui Undang-Undang Nomor 30 Tahun 2000 Tentang Rahasia Dagang harus dijalankan dengan benar sehingga para investor asing berkeinginan menanamkan modalnya di Indonesia, dengan demikan, penulis berharap bangsa Indonesia mampu bersaing dengan investor asing tersebut dalam era globalisasi.

\section{REFERENSI}

Gerungan, Anastasi E. 2016. Perlindungan Hukum Terhadaap Rahasia Dagang di Tinjau Dari Aspek Hukum Peerdata dan Pidana di Indonesia. Vol 22, No 5. Jurnal Hukum Unsrat.

Muasyara, Husnul, Dkk. 2016. Perlindungan Hukum Bagi Pemilik Rahasia Dagang di Tinjau dari UU No 30 Tahun 2000 Tentang Rahasia Dagang. Vol 5, No 2. Diponegoro Law Review.

Safnul, Dody. 2018. Perlindungan Rahasia Dagang dari Tindakan Persaingan Curang. ISSN: 1829-7463. Jurnal Warta Edisi 56. 